\title{
Barsak Mikrobiyotası ve Dayanıklılık Egzersizleri
}

\section{Gut Microbiota and Endurance Exercise}

\author{
Nesli ERSOY ${ }^{\mathrm{a}}$ Gülgün ERSOY ${ }^{\mathrm{b}}$
}

ÖZ Barsak mikrobiyotası; hormonal nitelikte çeşitli sinyal molekülleri üreterek, kan dolaşımı ile vücudun farklı bölgelerine ulaşabilen mikroorganizma kümeleridir. Mikrobiyota günümüzde birçok hastalıkla ilişkilendirilen güncel sağlık konularından birisidir. Mikrobiyotanın, egzersiz dâhil olmak üzere, çeşitli çevresel koşullar (beslenme, egzersiz, stres, doğum şekli) tarafindan düzenlendiğine ait günümüzde giderek artan kanıta dayalı bilgiler vardır. Son yıllarda ise, mikrobiyotanın egzersiz performansını olumlu etkilediği belirtilmektedir. Özellikle egzersiz süresinin uzun ve yoğun olduğu dayanıklıllk sporlarında sporcunun sağlıklı mikrobiyotaya sahip olmasının, enerji metabolizması, oksidatif stres ve hidrasyon durumu gibi kritik öneme sahip metabolizmaları olumlu etkilediği bildirilmiştir. Aynı zamanda, yorucu ve uzun süreli egzersize bağlı sporcuların sıklıkla yaşadıkları immün sistem baskılanmasında da iyileştirici etkilerinin olduğu belirtilmişsir. Bu şekilde sporcuların üst solunum yolu enfeksiyonu ve gastrointestinal sistem rahatsızlıklarının sıklık ve süresini azalttığına dair kuvvetli bilimsel veriler bulunmaktadır. Probiyotik kullanılması ile oluşan mikrobiyota değişiminin, inflamasyon ve redoks düzeylerini kontrol edebileceği, egzersiz yapan kişiler ve sporcuların; genel sağlık, performans ve enerji kullanılabilirliğini iyileştirmek için önemli bir beslenme stratejisi olabileceği belirtilmiştir. Mikrobiyotanın dayanıklılık egzersizi performansını etkilemesinin yanı sıra egzersiz yapımının da mikrobiyota zenginleştirilmesine katkıda bulunduğu bildirilmiştir. Önümüzdeki yıllarda egzersiz, immün sistem ve mikrobiyota ilişkisine odaklanan daha fazla araştırmanın yapılmasına gerek vardır. Bu derleme yazının amacı dayanıklılık egzersizi ve mikrobiyota ilişkisini inceleyen güncel literatür çalışmalarının özetlenmesidir.

Anahtar kelimeler: Dayanıklılık, egzersiz, barsak mikrobiyotası

\begin{abstract}
Gut microbiota; are hormonal clusters of microorganisms capable of producing various signaling molecules and reaching different regions of the body through blood circulation. Microbiota is one of the current health issues associated with many diseases today. There is increasing evidence-based knowledge that microbiota is regulated by a variety of environmental conditions (nutrition, exercise, stress, pregnancy ...), including exercise at the present time. In recent years, it has been reported that microbiota has a positive effect on exercise performance. It has been reported that the athlete has a healthy microbiota especially in the long and intense endurance sports during the exercise period, positively affecting metabolism with critical prescription such as energy metabolism, oxidative stress and hydration state. At the same time, intense and long-term exercise-based athletes have often been shown to have positive effects on immunosuppression. In this way there is strong scientific evidence that athletes reduce the frequency and duration of upper respiratory tract infections and gastrointestinal system disorders. The use of probiotics to control microbial alteration, inflammation and redox levels, exercise practitioners and sportsmen; it may be an important nutrition strategy to improve overall health, performance and energy availability. In addition to affecting the endurance exercise performance of microbiota, exercise production has also been reported to contribute to microbiota enrichment. Further research is needed in the years to focus on exercise, the immune system and the microbiota relationship. Purpose of this review is summarize current literature studies that examine the relationship between endurance exercise and microbiota.
\end{abstract}

Key words: Endurance, exercise, gut microbiome

\section{Giriş}

Dayanıklılık egzersizleri; koşu, kayak, bisiklete binme, yüzme gibi aerobik / kardiyovasküler egzersizler olarak tanımlanır. Dayanıklılık egzersizlerinin fizyolojik ve biyokimyasal

gereksinimleri; hem sistemik hem de kasa ait tepkilerin ortaya çıkmasına sebep olur. Dayanıklılık egzersizi sırasında vücut homeostazı, organlar ve vücut sisteminin normal fonk-

Geliş Tarihi/Received:01-02-2018 / Kabul Tarihi/Accepted: 27-08-2018

${ }^{a}$ Dr. Hacettepe Üniversitesi, Sağlı Bilimleri Fakültesi, Beslenme ve Diyetetik Bölümü, Araştırma görevlisi, e-posta: nesli.arpaci@ hacettepe.edu.tr ORCID: 0000-0003-0391-8848

bProf.Dr. İstanbul Medipol Üniversitesi, Sağlı Bilimleri Fakültesi, Beslenme ve Diyetetik Bölümü, Öğretim üyesi, e-posta:gulgun@ hacettepe.edu.tr, ORCID: 0000-0001-8345-5489

Sorumlu Yazar /Correspondence: Dr. Nesli Ersoy.Hacettepe Üniversitesi, Sağlık Bilimleri Fakültesi, Beslenme ve Diyetetik Bölümü, Araştırma Görevlisi, e-posta: nesli.arpaci@ hacettepe.edu.tr ORCID: 0000-0003-0391-8848

Atıf: Ersoy N, Ersoy G. Barsak mikrobiyotası ve dayanıklılık egzersizleri. Sağlık Bilimleri ve Meslekleri Dergisi 2019;6(1): 170-178

Citation: Ersoy N, Ersoy G. Gut Microbiota and endurance exercise. Journal of Health Science and Profession 2019;6(1): 170-178 
siyonunu bozan, aşırı fizyolojik koşullar ortaya çıkarabilir. Uzun süreli ve yüksek şiddette yapılan dayanıklılık egzersizleri; akut faz proteinlerinin sentezi ve hidrasyonu, hormonal ve metabolik dengede değişimler yolu ile vücutta savunma yanıtını başlatır (1). Dayanıklılık egzersizine adaptasyon; kastaki mekanik, metabolik, nöromüsküler ve kasılma işlevlerinin iyileştirilmesi, elektrolitlerin dengelenmesi, glikojen deposunda azalma ve kas dokusunda mitokondriyal biyogenezdeki artış ile sağlanır. Dayanıklılık egzersizleri ayrıca; oksidatif stres, barsak geçirgenliği, kas hasarı, sistemik inflamasyon ve bağışıklık tepkileri üzerinde de önemli bir etkiye sahiptir (1-2). Özetle dayanıkl11ık egzersizi vücut için önemli bir metabolik ve fizyolojik süreci başlatmaktadır. Bu sebeple, yoğun olarak dayanıklılık sporcuların bu yüklerinin azaltılması hedeflenmektedir. $\mathrm{Bu}$ çerçevede mikrobiyotanın bu zorlu sürece olumlu katkısının olabileceği düşünülmüştür.

Konakçı ile etkileşime giren dinamik bir bakteri topluluğu olan barsak mikrobiyotası, insan metabolizmasını ve bağışıklık fonksiyonlarını düzenler ve insan sağlığının ayrılmaz bir parçasıdır. İnsan bağırsağı; beslenme, metabolik fonksiyonlar, barsak gelişimi, immün sistem ve epitel hücrelerin olgunlaşmasını önemli derecede etkileyen çok sayıda mikroorganizmayı barındırır. Barsak mikrobiyotası enerji oluşumu için sindirim ve emilimi desteklerken, kolondaki kompleks karbonhidratlar sindirilir ve n-bütirat, asetat ve propiyonat gibi kısa zincirli yağ asitlerine (KZYA) fermente edilir. Propiyonat ve asetat kan dolaşımı ile çeşitli organlara taşınır ve enerji metabolizması için substrat olarak kullanılır (3). Barsak mikrobiyotası aynı zamanda patojen mikroorganiz-malardan koruyarak, epitel hücrelerin uyarılması ve olgunlaşmasını sağlayarak, konakçı bağışık-lık sisteminin fonksiyonlarının sürdürülmesi ve uyarılmasında önemli rol oynar. Dayanıklılık sporcularında, mukoza kalınlığının bozulması ve bakteri translokasyonunun (barsak lümenindeki canlı ve cansız bakteri, virüs, mantar gibi mikroorganizmaların ve/veya bunların ürettiği endotoksinlerin barsak bariyerini geçerek, portal sistemik dolaşıma ulaşması) artması sonucu "geçirgen barsak sendromu" olarak da adlandırılan gastrointestinal epitel duvarının geçirgenliğinin artmas1 ile üst solunum yolu enfeksiyonları (ÜSYE) ve gastrointestinal rahat-sizlıklar s1k görülebilmektedir (3-4).

$\mathrm{Bu}$ derleme yazıda, barsak mikrobiyotasının dayanıklılık egzersizi üzerine etkilerinin incelendiği güncel literatür bilgilerine yer verilmiştir.

\section{Egzersize Bağlı Barsak Mikrobiyotasındaki Değişiklikler}

Gastrointestinal sistem mikrobiyotasının; besin ögesi metabolizması, bağışıklık cevabının gelişmesi, patojenlerden korunma ve epitel hücre çoğalmasının uyarılması da dâhil olmak üzere, sağlık ve performans üzerindeki etkisi giderek daha önemli hale gelmiştir. İnsanlarda, barsak mikrobiyota bileşiminin ve işlevlerinin bozulmasının ise konakçı metabolizması ve hastalıklarının gelişiminde önemli bir rol oynayabileceği düşünülmektedir $(1,3)$.

Barsak mikrobiyomunun (mikrobiyotanın genomik içeriği) kişinin egzersiz performansına katkısı hakkında az şey bilinmesine karşın, egzersizin barsak mikrobiyotası bileşiminde değişikliğe neden olduğu gösterilmiştir. Düzenli yapılan, orta düzey egzersizlerin, firmicutes bakterileri (Faecalibacterium prausnitzii, Oscillospira, Lachnospira, Coprococcus) çeşitliliğini önemli ölçüde artırdığı ve daha sağlıklı bir barsak ortamına katkıda bulunduğu belirtilmektedir (5). Hayvanlar üzerinde yapılan çalışmalarda, egzersizin dışkıda bacteroidetes (gram-negatif, çubuk şekilli bakteriler) türlerini artırdığ 1 ve firmicutes türlerinde azalmaya neden olduğu ve 6 haftalık egzersizi takiben, çekum mikrobiyotasında, firmicutes türlerinde artışa ve Bacteroidetes/Prevotella türlerinde düşüsse neden olduğu saptanmıştır (6-8). Benzer şekilde bir başka çalışmada, ratlarda egzersize bağlı olarak bacteroidetes türleri azalırken, firmicutes, proteobacteria ve actinobacteria' da artış olmuştur (9-10). Amerikan Barsak Projesinin (American Gut Project) ( $\mathrm{n}=1493)$ sonucuna göre; egzersizin dışk1 bakteri çeşitliliğinde özellikle de firmicutes familyasının bazılarında artışa neden olduğu bulunmuştur (5). Elit ragbi oyuncularında yapılan araştırmada ise sedanter kişilerle karşılaştırıldığında, sporcuların, daha fazla barsak mikrobiyal çeşitliliğine sahip oldukları belirlenmiştir. Aynı zamanda, beden kütle indeksi düşük olan sedanter kişilerde Akkermansia türü mikroorganizma önemli oranda yüksek bulunmuştur. $\mathrm{Bu}$ durum daha sağlıklı bir metabolik profil ile ilişkilendirilmiş ve artmış mikrobiyal çeşitliliğin egzersizin yararlı etkilerinden biri olduğu belirtilmiştir (11). Yapılan başka bir çalışmada; erkek, elit ragbi oyuncularının sporcu olmayan sağlıklı kişilerle dışkı bakteri profilleri karşılaştırılmıştır. Sporcuların, protein tüketimi ve kreatin 
kinaz düzeyleri pozitif yönde ilişkili bulunmuş ve 22 farklı familyadan oluşan barsak mikroorganizmalarının daha fazla çeşitliliğe sahip olduğu görülmüştür. Sonuç olarak, egzersizin barsak mikrobiyotik çeşitliliği üzerine olumlu bir etkisi olduğu bulunmuş, bu etkinin kompleks ve beslenme ile ilişkili olduğu belirtilmiştir (12). Ratlar üzerinde yapılan sadece bir çalışmada, barsak mikrobiyotasının performansa etkisi değerlendirilmiştir. Literatürlerin çoğu, egzersizin barsak mikrobiyotasına etkilerine odaklanırken, yapılan bu çalışmada üç cins (Spesific Pathogen Free- SPF, Germ FreeGF, Bacteroidetes Fragilis-BF gnotobiotic ratlar) rat üzerinde mikrobiyotanın yüzme zamanına etkisi araştırılmıştır. Araştırmacılar, dayanıklılık performansını SPF ve BF ratlarında, GF ratlarına göre daha yüksek saptamışlar ve bu sonuca göre barsak mikrobiyota içeriğinin, egzersiz performansı için çok önemli olduğunu ve potansiyel olarak sporcularda antioksidan enzim sistemleriyle bağlantılı olabileceğini düşünmüşlerdir (3). Gelecekte barsak mikrobiyota profilinin geleneksel tanı yöntemleri yapılmadan önce; performansı ön görmek ve potansiyel sorunları algılamak için bir kriter olabileceği sorusu akıllara gelmektedir $(1,3)$.

\section{Barsak Mikrobiyotasının Enerji Metabolizmasındaki Rolü}

Dayanıklılık egzersizleri sırasında enerji kullanım1, performansı sınırlayan önemli faktörlerden biridir. Birkaç dakika süren kas kasılmalarından sonra, fosfokreatin (PCr) konsantrasyonu azalarak, diğer yakıtların kullanılmasına gerek duyulur. Bu uyaran hızla algılanır ve sinyal yolları vasıtasıyla koordineli bir şekilde transkripsiyonel (DNA'dan RNA'ya genetik bilginin aktarımıdır), transkripsiyon sonras1 ve allosterik tepki (özel küçük moleküllerin, bir proteinin aktif merkezinden başka bir yere bağlanması sonucu biyolojik özellikleri değişen proteinler) haline dönüştü-rülür ve hücresel enerji dengesini yeniden sağlamak için gerekli spesifik moleküllerin sentezine yol açar. İlk olarak, ATP ve kas iyon pompasının talebini karşılamak için glikogenoliz ile ilgili genlerin transkripsiyonu başlat1lır. Mitokondride yüksek şiddetteki egzersizler sırasında oluşan piruvatın tamamı okside edilemez ve laktata dönüşür. Bunun sonucunda oluşan hücre içi asidoz, enerji metabolizmasını baskılayarak yorulmaya neden olabilir. Ayn zamanda yağ dokusunda oluşan lipoliz; yağ asitlerinde artış yanı sıra plazma serbest yă asidi alımı (uptake) ve yağ asidi oksidasyonuna katkıda bulunur $(13,14)$.

Dayanıklılık egzersizleri süresince, enerji gereksiniminin karşılanmasının mikrobiyota ile ilişkisi karmaşık olsa da, son yıllarda ilgi odağ1 olmuştur. Bitkisel polisakkaritler (selüloz, $\beta$ glukan, ksilan, mannan ve pektin) kolonda barsak mikroorganizmaları tarafından KZY'lara fermente edilerek diğer bakteriler tarafindan enerji kaynakları olarak da kullanılır. KZYA'lar; enerji kullanımı, konakçı-mikroorganizma sinyali, kolon pH'sının kontrolü dâhil olmak üzere barsağın mikrobiyotik içeriği, barsak hareketleri, barsak geçirgenliği ve epitel hücre çoğalması yoluyla konakçının vücut fonksiyonlarını etkiler (1). Örneğin n-bütiratın, hücre kültürü ve hayvan çalışmalarında adipositlerdeki leptin üretimini uyararak, ayrica glukagon benzeri peptid 1 (GLP-1) salımını sağlayan barsak endokrin L hücrelerini provake ederek, enerji dengesini sağladığı gösterilmiştir. Clostridia, Eubacteria ve Roseburia, n-butirat oluşturan temel türlerdir. Barsak bakterileri tarafından oluşturulan nbütirat, nötrofil fonksiyonlarını ve göçünü düzenler, kolon epiteline sık1 bağlantılı proteinlerin ifadesini artırarak antiinflamatuvar etkiler gösterir. Propiyonat ve asetat gibi diğer KZYA'lar, karaciğer ve periferik organlarda (örneğin kas ve yağ dokusu) glikoneogenezis ve lipogenez için substrat kaynağıdır. Barsak mikroorganizmaları tarafindan oluşturulan KZYA türleri ve miktarı, barsak mikrobiyotasının bileşimi ve mikrobi-yotik türler arasındaki metabolik etkileşimler, aynı zamanda da tüketilen diyetin makro ve mikro besin ögelerinin miktarı, türü ve dengesine göre belirlenir (15).

Besin tüketimi bireylerin mikrobiyotas 1 üzerine etkili olmakta, özellikle sporcuların besin tüketimlerinde protein ve karbonhidrat miktarının fazla olması ise mikrobiyotay 1 değiştirmektedir. Amino asitlerin fermantasyonu, KZYA gibi yararlı ara ürünler oluşturmasına karşın, potansiyel olarak zararlı bileşikler de oluşabilir. Hayvan ve in vitro araştırma sonuçları; amonyak, fenoller, p-kresol, bazı aminler ve hidrojen sülfit gibi bileşiklerin, "geçirgen barsak sendromu" ve inflamasyonun başlatılması veya ilerlemesinde önemli rol oynadığını göstermiştir (1). Bu nedenle mikrobiyotanın düzenlenmesini, egzersiz sırasinda karbonhidrat fermentasyonunun artırılmasin1 ve protein metabolizması sonucu oluşan toksik metabolitlerin sinırlanarak performansin artırılmasını amaçlayan diyetler tasarlamak 
önemli bir beslenme stratejisi olabilir. Sporcular daha fazla enerji, yăg, karbonhidrat, protein, protein destekleri ve doymuş yağ tüketir. Bu nedenle, diyetin barsak mikrobiyal çeşitliliği ve egzersiz performansı üzerindeki etkisi değerlendirilmelidir. Diyette yapılan değişiklikler veya egzersizin, elit spor-cuların barsak mikrobiyota profilini etkileyip etkilemediğini belirlemek için prospek-tif çalışmalar yapılmalıdır. Eğer; barsak mikro-biyota içeriğinin düzenlenmesinin, serum glikoz düzeyi ve karaciğer yağlanmasına olumlu etkileri de kantlanırsa, egzersiz ve barsak mikrobiyota içeriğinin düzenlemesi yoluyla, kronik hastalıklarla mücadele için yeni stratejiler ortaya çıkacaktır $(1,2,4)$.

\section{Barsak Mikrobiyotasının Bağışıklık Yanıtına Etkisi}

Yoğun egzersizlerin bağışıklık yanıtını baskıladığ1 ve toplam lökosit, granülosit, monosit, lenfosit, doğal öldürücü hücre, toplam T hücre sayıları, mitojenlere yanıt olarak hücre çoğalması ve serum immünoglobülin düzeylerinin değiştiği bildirilmektedir (16). Yoğun egzersizler sürdürüldügünde, plazma kortizol düzeyleri yükselerek kemik iliğinden nötrofil ve diğer lökosit alt gruplarında dışarı akış/sızıntı meydana gelir. Hücresel bağışıklıkta oluşan değişikliklere ek olarak, yoğun egzersizlerin sepsis ve travma olaylarında görülen akut faz inflamatuvar cevaplarına benzerlik gösteren çeşitli çalışmalar da vardır (1). Sağlık için yapılan egzersizlerin aksine, yoğun ve uzun süreli egzersizler, TNF- $\alpha$, IL-1, IL-6, IL-1 reseptör antagonisti, TNF reseptörleri gibi pro-inflamatuvar sitokinlerin sayısının yanı sıra, anti-inflamatuvar düzenleyicilerin (IL-10, IL-8 ve makrofaj inflamatuvar protein-1) sayısını artırır (3).

Yaz ve kış olimpiyat oyunlarına (2014 y1lı) katılan sporcuların, \%7.2- 8.9'unun sağlık sorunu yaşadığı, bu sorunların \%46-58'inin enfeksiyon kaynaklı olduğu bildirilmiştir $(17,18)$. Patojenlere maruz kalma olasılıkları; egzersiz sırasında akciğer ventilasyonunda artış, cilt aşınmaları, kalabalık ortamlarda bulunmaları nedeniyle artabilir. Sporcular; dengesiz beslenme, yurtdış1 seyahatlerinde değişen zaman dilimi, rahat olmayan uyku ve değişen çevresel koşullara maruz kalmanın yanı sıra egzersizin fiziksel ve psikolojik stresinden dolayı da ÜSYE'ye daha yatkındır $(1,18)$. Uzun süreli ve yoğun aerobik egzersizlerin, barsak lenfositlerinde TNF- $\alpha$ ve IL-10'da artışa neden olduğu bildirilmiştir. Ayrıca yoğun egzersizlerin bakterileri kaplayan ve bağışıklığı artıran, inflamatuvar olmayan bir konakçı-mikrobiyal ilişki sürdürmesine yardımc1 olan, immünoglobülin A (IgA)'nın ifadesini artırdığı ve böylece egzersiz yapan ratların enfeksiyonlara karşı direncinin güçlendirilebildiği gösterilmiştir (1). Bu bulgunun aksine, yat yarışlarına katılan elit sporcular üzerinde yapılan bir çalışmada, egzersiz yükü arttıkça, tükürük IgA düzeylerinin azaldığı açıkça görülmüştür (19). $\mathrm{Bu}$ bulgular sonucunda, bağışıklığın bozulması ile "açık pencere" olarak tanımlanan, virüslerin ve bakterilerin dayanıklılık sporcularında subklinik ve klinik enfeksiyon riskini artırma olasılığına ait bir teori ortaya çıkmıştır. Aslında yorucu egzersizlerin sporcularda, ÜSYE prevalansını ve sindirim rahatsızlıklarını artırdığı bilinir $(1,17,18)$.

Dayanıklılık egzersizlerinde bağışıklık yanıtını değiştiren diğer yol; inflamatuvar immün yanıtı uyaran barsak mukoza kalınlığının bozulması, gastrointestinal epitel duvarının geçirgenliğinin artması, dokularda oluşan hipertermi sonucu azalan kan akışı, oksijen ve taşınan besin ögelerinin azalmasıdır. Geçirgen barsak olarak adlandırılan bu durum, patojenler veya endotoksinlerin barsak bariyerinden, kan dolaşımına geçerek, bağışıklı sisteminin mikrobiyotik dengesinin bozulmasina neden olan endotoksemiye yol açabilir. Stresli koşullarda, barsak epitel hücreleri arasındaki çözünen maddelerin ve sıvıların parasellüler geçişini sıkı bir şekilde kontrol eden kavşakların gevşemesi sonucunda, bağışıklık cevabını provoke eden daha büyük maddelerin barsaklardan kaçmasına neden olabilir. Egzersize bağlı olarak sık1 kavşakların gevşemesi; bakteri hücreleri tarafından ifadesi değiştirilen motifleri tanıyabilen özel toll-benzeri reseptörler (Tolllike receptors-TLRs) (mikroorganizmalar tarafindan oluşturulan ve yapısal olarak korunmuş moleküller, deri veya barsak mukozası gibi fiziki bariyerleri aştığında, bu molekülleri tanıyan tek membran boyunca uzanmış, katalitik-olmayan reseptörlerin bir sinıfıdır) ile dinamik bir etkileşim sonucunda gerçekleşir. Bir yandan TLRs'lerin aktivasyonu ile uyarılmalar başlar, bu uyarılmalar gastrointestinal sistemde proinflamatuvar ve sitokinlerin salımını uyaran proteinlerin ve transkripsiyon faktörlerinin aktive edilmesidir. Aslında, sağlıklı kişilerde, kommensal bakterilerin (konakçı üzerinde veya içinde yaşayan, ancak konakçısına zarar vermeyen organizmalar) portal ven yoluyla karaciğere erişemediği, kan endotel hücreleri boyunca translokasyona tabi tutulan antijenleri 
kontrol eden barsak-vasküler bariyerin varlığ 1 nedeniyle dalağa ulaşamadığı gösterilmiştir. Barsak-vasküler bariyerinin yüksek şiddette yapılan egzersizlerle tehlikeye girip girmediği henüz bilinmemektedir $(1,3)$.

Diğer çalışmalarda, aşırı egzersizin neden olduğu intestinal geçirgenliğin artmasının, serum endotoksisitesini artırdığ 1 , aynı zamanda bağışıklık yanıtını uyardığı gösterilmiştir. Yapılan bir çalışmada, endotoksin olan lipopolisakkarit düzeyleri triatlondan önce, hemen sonra ve 1, 2, 16 saat sonra, 29 sporcudan alınan kan örneklerinde bakılmıştır. Yüksek şiddette egzersizler sonrasında, barsak geçirgenliğinde bir artış olduğu anlamına gelen lipopolisakkarit düzeylerinde egzersizden hemen sonra artış saptanmış, yarıştan 1 saat sonra ise daha yüksek bulunmuştur. Yarıştan 1 saat sonra sporcuların \%68'inde endotoksemi görülmüştür (20).

Yüksek şiddette egzersizlerin neden olduğu inflamatuvar yanıtın önlemesi için, barsak mikrobiyotası ve KZYA'lar kolonik mukoza geçirgenliğini azaltabilir ve inflama-tuvar sitokinleri inhibe edebilir. Barsak mikrobiyotasının bu anti-inflamatuvar etkileri, dayanıkl11ık performansin 1 etkileyen yorgunluk belirtilerini geciktirmeye yardımc1 olabilir. Barsak mikrobiyota içeriğinin ve yapısının, dayanıklılık egzersizi sirasinda ve sonrasinda metabolik ve sistemik stresi izlemek için yararlı bir biyolojik belirteç olabileceği düşünülebilir. Mikrobiyal çeşitlilik, profesyonel sporcular arasında gastrointestinal ve solunum yolu rahatsılıkları ile ilişkili olduğu için ve bağışıklık tepkilerini barsak mikrobiyotasının düzenlenmesi yoluyla desteklenmesine yardımcı olan beslenme alışkanlıklarını keşfetmek (örneğin probiyotik destekleri kullanmak) önemlidir (4).

\section{Barsak Mikrobiyotasının Oksidatif Stres Üzerine Etkisi}

Dayanıklılık egzersizlerinin temel fizyolojik adaptasyonlarından biri; doku hasarını, barsak geçirgenliğini ve bakteriyal translokasyonu önlemenin bir yolu olan oksidatif ve nitrosatif strestir. Gastrointestinal sistem, normal hücre metabolizmasının ara ürünlerinden olan reaktif oksijen türlerinin (ROS) ve azot oksit türlerinin (RONS) önemli bir kaynağıdır. Barsak epitel redoks ortaminın dengesi, antioksidan savunma ve/veya oksidatif stres arasındaki denge ile sağlanır. ${ }^{1}$

Reaktif oksijen türleri (ROS), normal hücresel metabolik aktivitelerin yan ürünleri olarak üretilir. Süperoksit dismutaz, glutatyon peroksidaz ve katalaz, ROS ve RNOS'un zararlı etkilerinden hücreleri korumada rol oynayan enzimlerdir. Redoks sinyali yoluyla normal hücresel homeostazın bozulmasi; kardiyovasküler, nörodejeneratif hastalıklar ve kansere neden olabilir. ROS gastrointestinal sistem içinde üretilir. Mukozanın sağladığı koruyucu bariyere karşın, tüketilen yiyecekler ve mikrobik patojenler, epitelyum ve inflamatuvar hücrelerini içeren oksidatif hasar ve gastrointestinal inflamatuvar yanitları uyarır. Peptik ülserler, gastrointestinal kanserler ve inflamatuvar barsak hastalığı da dahil olmak üzere çeşitli gastrointestinal hastalıkların patogenezi kısmen oksidatif stres kaynaklidır. Yani barsak mukozası ayrıca patolojik koşullara yol açabilen çeşitli oksidanlar için bir hedeftir. Oksidatif stres, birçok gastrointestinal mukoza hastal1ğının patogenezine önemli bir katkı sağlar $(3,21)$.

Mikrobiyotanın gastrointestinal redoks ortamını kontrol edici etkisi henüz araştırma aşamasındadır. Yapılan bir çalışmada, oksidatif durumun Lactobacillus ve Bifidobacterium ile negatif, barsak Escherichia coli ile pozitif korelasyon gösterdiği bulunmuştur (22). Ratlar üzerinde yapılan çalışmalarda, barsak mikrobiytasının konakçının amino asit metabolizmasını etkilediği ve böylece glutatyon metabolizmasını düzenlediği bildirilmiştir $(23,24)$. Daha önce de belirtildiği gibi, mikrobiyotanın zayıflığı, antioksidan enzim aktivitelerini ve egzersiz performansını düşürür. $\mathrm{Bu}$ nedenle araştırma sonuçlarına göre, farklı mikrobiyota içerik ve yapılarının, CAT ve GPx gibi antioksidan enzimlerin aktivitesini değiştirerek, egzersiz performansını etkileyebileceği sonucuna varılmıştır (1). Mikrobiyotanın egzersiz sırasında redoks dengesinin kontrolü üzerindeki rolünün açıklanması için daha çok araştırma yapılmas1 gerekir.

\section{Barsak Mikrobiyotasının Dehidrasyon Üzerine Etkisi}

Dayanıklılık sporcuları; egzersizin uzun süreli ve yüksek şiddette olması nedeniyle dehidrasyon riski altındadır ve vücut ağırlığının \%2'si kaybedildiği durumlarda performans olumsuz etkilenmektedir. Vücut ağırlı̆g $\% 5$ 'den fazla kaybedildiğinde ise performans yaklaşık \%30 oranında azalabilir. $\mathrm{Bu}$ nedenle dayanıklılık performansı için yeterli hidrasyonun sağlanması gerekir. Mukozal epitel hücrelerin temel fizyolojik fonksiyonu, elektrolitleri taşımaktır. Suyun taşınması ve mukozal hidrasyonu 
sağlamak, barsak bariyerinin korunması ve barsağın normal işlevi için gereklidir $(1,25)$.

Yapılan bir çalışmada, barsak mukozasinda klor sekresyonunun, Lactobacillus (firmicutes phylum) ve Alistipes türlerini artırarak, mukus ve barsak mikrobiyota içeriğini değiştirdiği bildirilmiştir (26). Başka bir çalışmada da, klor sekresyonunun primer savunma mekanizması olarak işlev gördüğü ve mikrobiyotada önemli değişiklikler (firmicutes ve bacteroidetes familyasının sayısını artırarak) yaptığı bildirilmiştir. Barsak mikrobiyotasının, egzersiz sirasinda uygun hidrasyon düzeyinin sürdürülmesi ve inflamatuvar bir yanıtın önlenmesi ile ilgili olduğu düşünülmektedir (27). Redondo ve arkadaşları, 23 sağlıklı genç bireyde Clostridium türünün plazma osmolalitesini, bacteroidetes familyasının ise plazma sodyum düzeylerini düşürdüğünü göstermiştir. Plazma sodyum konsantrasyonu, potasyum, bikarbonat, üre ve glikoz ile birlikte toplam osmolalitenin \%95'ini oluşturur. Bu sonuç mikrobiyotanın; çözeltilerin mukozadan hücresel olarak taşınmasını etkilediği, hidrasyon durumuna katkıda bulunduğu, ayrıca plazma osmolalitesini düşürdüğü düşüncesini oluşturur. Aynı çalışmada Bifidobacterium fazlalığının, konakçının bağışıklık tepkisi ile etkileşimini yansitan $\mathrm{T}$ lenfosit düzeylerini de etkilediği bulunmuştur (28). Ultra-dayanıklılık sporcuları egzersiz sirasinda genellikle sivı gereksinimlerini karşılamakta zorlanır, bu nedenle iyi bir hidrasyon durumu ve barsak bariyerinin korunması, spor performansı için önemlidir. Mikrobiyotanın suyun taşınması ve barsak mukus tabakasında oluşan değişikliklere etkisini yapılacak olan yeni çalışmalarla açıklanması büyük önem taşımaktadır (29).

\section{Beslenme Müdahalelerinin Mikrobiyota Profiline Etkisi}

Barsak mikrobiyotasının, sağlık ve hastalıklarla ilişkisini araştıran çalışmaların genel amacı; yaşam tarzı değişiklikleri, beslenme ve barsak mikrobiyotası arasındaki ilişkinin işlevsel sonuçlarını araştırmaktır. Günümüzde probiyotiklerin, prebiyotiklerin, polifenollerin ve antibiyotiklerin kullanılmasının, barsak mikrobiyotasını değiştirdiği bilinmektedir. Probiyotiklerin, sporcunun barsak sağlı̆ğ, redoks biyolojisi ve bağışıklığı üzerinde olumlu etkileri olduğu öne sürülmektedir(1). Bu sebeple beslenme müdahalesi ile mikrobiyal zenginliğin sağlanması her geçen gün değer kazanmaktadır.
Egzersiz yapan kişilerde, düzenli probiyotik tüketimi, barsak mikrobiyotasını ve yapıs1n1 değiştirebileceği, bağışıklık fonksiyonlarını etkileyebileceği, bunun yanı sıra barsak epitel hücrelerinin çoğalması, işlevi ve koruması ile ilgili olumlu sonuçların olduğu belirtilmektedir (30). Probiyotikler, canlı mikroorganizmaları, özellikle laktik asit bakterilerini içeren besin destekleridir. Yeterli miktarda tüketildiğinde, konakçı için yarar sağlar. Ticari olarak tabletler, kapsül formları, tozlar (içeceklere eklenir), probiyotik açısından zengin sakızlar, fermente süt veya yoğurt gibi bazı süt ürünlerinde bulunurlar (31).

Sporcularda probiyotiklerin kullanılmasina olan ilgi, ÜSYE'nin ve gastro intestinal sistem (GIS) rahatsızliklarının semptom ve sıklıklarının önlenmesi ve azaltılmasına yöneliktir $(30,32)$. Probiyotik yoğurdun etkileri 46 kadın dayanıklılık yüzücüsü üzerinde incelenmiştir. Araştırma grubu, Lactobacillus acidophilus, Lactobacillus delbrueckii bulgaricus, Bifidobacterium bifidum ve Streptococcus salivarus thermophilus içeren 400 $\mathrm{mL}$ probiyotik yoğurt tüketirken, kontrol grubu aynı miktarda normal yoğurt $(L$. delbrueckii subsp. Bulgaricus ve S.thermophilus'un bir kültürü kullanılarak üretilen) tüketmiştir. Probiyotik yoğurt tüketmenin, yüzme yarışından sonra solunum yolu enfeksiyonlarının atak sayısında ve semptomların bazılarının süresinde azalmaya neden olduğu gözlenmiştir. Probiyotik yoğurdun tüketilmesinin, ÜSYE'yi azaltmas sonucu, maksimum oksijen tüketiminde belirgin bir iyileşme sağlaması olasılığı da belirtilmiştir (33).

Cox ve arkadaşlarının 20 elit mesafe koşucusu üzerinde yapmış olduğu çalışmada; probiyotik (Lactobacillus fermentum VRI003'ün (PCC)) kullanan sporcular plasebo grubu ile kıyaslandığında, bir ay süre ile yapılan PCC müdahalesinin 30 günü boyunca görülen ÜSYE semptomlarının gün sayısının, yarı yarıya azaldığını rapor etmiş̧lerdir. PCC müdahalesi sırasında görülen hastalık şiddetinin daha hafif olduğu da belirlenmiş, ama tükürük $\operatorname{IgA}$ düzeyleri veya interlökin (IL-4 ve IL-12) düzeylerinde anlamlı farklılık bulunmamıştır. Fakat koruyucu olarak probiyotik tedavisi, tam kan kültüründe interferon gamma (IFN $\gamma)^{\prime}$ da 2 kat daha fazla değişiklik meydana getirmiş, bu da IFN $\gamma$ düzeylerinin korunmasının pozitif klinik sonuçlar için altta yatan bir neden olabileceğini düşündürmüştür (34). 
Yapılan başka bir araştırmada, 4 ay süre ile Lactobacillus casei desteği yapılan, 42 dayanıkl111k sporcusunda deney grubunda olanlar kontrol grubu ile kıyaslandığında, ÜSYE hastalıklarının prevalansında azalma olduğu gösterilmiş, kış ayları süresince tükürük $\mathrm{IgA}$ düzeylerinde iyileşmeler görülmüştür (35). Yapılan diğer çalışmalarda, probiyotik desteğinin sitokinler ve bağışıklık göstergelerini geliştirdiği, oksidatif stresi azalttığı, ayrıca solunum ve gastrointestinal semptomlara olumlu etkiler yaptığı belirtilmiştir (30,32). Örneğin, West ve arkadaşları yaptıkları çalışmada, 28 gün boyunca probiyotik desteğinin (Bifidobacterium animals subsp. lactis; $2 \times 10^{9}$ CFU/gün), 461 sağlıklı, aktif erkek ve kadınların oluşturduğu deney grubunda plasebo grubuna kiyasla, solunum ve gastrointestinal sorun yaşama risklerinde azalma olduğunu bulmuşlardır. Kadın ve erkeklerin probiyotik desteğine farklı cevap verip vermediklerini incelemek için, $L$. fermentum desteği yapıldıktan 88 gün sonra, solunum ve gastrointestinal semptomlarda erkeklerde önemli bir azalma gözlenmiş, ancak kadınlarda herhangi bir değişiklik görülmemiştir. İki cinsiyet arasındaki görülen farklılıkların, biyolojik ve/veya çevresel faktörlerden kaynaklanabileceğini belirtmişlerdir (32).

Probiyotikler, egzersize bağlı oksidatif strese karşı koruyucu olabileceği düşüncesi ile yapılan bir çalışmada; 14 hafta süresince, çoklu probiyotik desteği yaptıkları antrenmanlı erkeklerde, dışkı zonulin düzeylerinin (barsak bariyer bütünlüğünü gösterir, barsak bariyerinde bir bozukluk olduğunda ve barsak geçirgenliği arttığında kanda düzeyi artar) plasebo grubu ile kıyaslandığında azaldığını göstermişlerdir. Ayrıca TNF- $\alpha$ ve egzersize bağlı protein oksidasyonunu olumlu etkilendiğini, bu nedenle antrenmanlı sporcularda probiyotik kullanımının umut verici yararları olduğunu belirtmiş̧lerdir (36). $L$. rhamnosus veya $L$. paracasei ile probiyotik desteğinin, sporcularda plazma antioksidan düzeylerini artırarak, yüksek şiddetli egzersize bağlı oluşan oksidatif stresi azalttığı belirtilmiştir (37). Dominant olarak Lactobacillus ve bifidobacterium suşlarının se-çilmesi sonucunda, sıkı bağlantılı proteinlerin ekspresyonunu artırarak, çeşitli fizyolojik stres faktörlerine cevap olarak barsak bariyerinin bütünlügünü koruduğu gösterilmiştir(1).

Kuvvet antrenmanı yapan kişilerde, protein ve probiyotiklerin birlikte verilmesinin, dikey sıçrama gücünü artırdığına dair yapılan bir çalışmada, önce $20 \mathrm{~g}$ kazein (protein), daha sonra 20 g kazein+probiyotik (1 milyar $C F U$ bacilluscoagulans GBI-30,6086, PROBC) verilmiştir. Suplemantasyondan iki hafta sonra probiyotik desteği sadece protein desteği ile kıyaslandığında, 24 ve 72 saatte toparlanmanın arttığı, kas ağrılarının ise egzersiz sonrası 72 saatte azaldığ 1 bulunmuştur. Kas hasarının göstergesi olan yüksek kreatin kinaz düzeyinin, probiyotik desteği ile çok daha fazla azaldığ 1 görülmüştür. Egzersize bağlı kas hasarının diğer göstergeleri olan kaslarda şişme ve kan üre nitrojen düzeyi arasında iki destek grubunda da farklıl1k görülmemiştir. Antrenman performansları ise, protein desteği yapıldığında azaldığı, probiyotik desteği yapıldığında performansın sürdürüldüğü belirlenmiştir (38). Bu çalışma dışında probiyotiklerin doğrudan performans1 artırdığı ya da toparlanma dönemindeki olas1 yararlı etkisi hakkında kanıta dayalı veriye ulaşılamamıştır.

Prebiyotikler, fermente edildiğinde bifidobacteria veya bazı bütirat ürünlerinin düzeylerinin artırılması gibi barsak mikrobiyota bileşiminde önemli değişiklikler yapabilen belirli bir diyet posası türüdür ancak prebiyotiklerin performans üzerine etkileri henüz araştırılmamıştır. Barsak mikrobiyotası; diyetle alınan polifenolleri, biyo-aktif polifenol metabolitlerine dönüştürmekte kritik bir rol oynar. $\mathrm{Bu}$ da mikrobiyota içeriği ve konakçı sağlığ için yarar sağlar. Bu veriler, bazı fonksiyonel besinlerin sporcuların sağlık ve performansına katkıda bulunma olasılığını artırmaktadır. Aynı zamanda şarap, kakao ve yaban mersini gibi polifenol içeren ürünlerin tüketilmesinin, bifidobacteria ve lactobacilli miktarını artırarak, barsak mikrobiyotasını daha "sağlıklı bir profile teşvik eden" konuma dönüştürdüğünü belirtilmektedir (1). Mikrobiyo-ta ve dayanıklılık egzersiz performansı ilişkisi bu iki parametre açısından da değerlendirilmelidir.

\section{Sonuç}

Son on yılda insan mikrobiyotası ve sağlikla olan ilişkisine olan ilgi artmış ve mikrobiyotayı etkileyen etmenler araştırılmaya başlanmıştır. Egzersizde mikrobiyota ile ilişkisi incelenen bu konulardan birisidir. Dayanıklılık egzersizleri sırasında; geçici immün baskılanma ve inflamatuvar değişikliklerin gözlenmesi ve bu mekanizmalarında barsak mikrobiyotas ile ilişskili olması, egzersiz ve mikrobiyota ilişkisini güçlendirmiştir. Barsak mikrobiyotası, oksidatif stresi azaltması ve sporcularda sıklıkla karşılaş1lan enfeksiyon hastalıklarının sıklık ve süresini 
azaltarak sağlık durumlarını olumlu etkilediği ve aynı zamanda yorgunluğu geciktirerek ve enerji sağlayarak dayanıklılık performansını artırdığg 1 düşünülmektedir. Bu sebeple, sporcuların, farklı Lactobacillus ve Bifidobacterium suşları ile desteklenmesi, genel sağlık durumunun korunması, bağışıklık fonksiyonlarının artırılması, barsak mukozal geçirgenliğinin iyileştirilmesi, oksidatif stresin azaltılması ve spor performansının artırılmasına destek olacağı düşüncesi ile probiyotik destek sağlanabilir. Ancak her yeni uygulamada olduğu gibi probiyotik destekleri ilk defa denenecekse müsabaka dönemi dışındaki antrenman dönem-lerinde denenmelidir. $\mathrm{Bu}$ şekilde spor perfor-mans1, probiyotiklerin olas1 yan etkilerinden etkilenmemiş olacaktır. Çeşitli sporcu grupla-rında probiyotik destekler ile barsak mikrobiyotası arasındaki karmaşık ilişkileri anlamak için daha iyi tasarlanmış çalışmalar (beslenme, aktivite düzeyi, doz, en uygun bakteri türü...) yapılması gerekmektedir.

\section{Kaynaklar}

1. Mach N, Botella DF. Endurance exercise and gut microbiota: A review. JSHS. 2017;6(2):179-197.

2. Cronin O, Molloy MG, Shanahan F, Exercise, fitness, and the gut. Curr Opin Gastro. 2016;32(2):67-73.

3. Cerdá B, Pérez M, Pérez-Santiago JD, Tornero-Aguilera JF, González-Soltero R, Larrosa M. Gut Microbiota Modification: Another Piece in the Puzzle of the Benefits of Physical Exercise in Health? Front Physiol. 2016;18(7):51.

4. Bermon S, Petriz B, Kajënienè A, Prestes J, Castell L, Franco OL. The microbiota: an exercise immunology perspective. Exerc Immunol Rev. 2015;21:70-79.

5. McFadzean R. Exercise can help modulate human gut microbiota. Boulder, Co: University of Colorado; 2014. [Dissertation].

6. Evans CC, LePard KJ, Kwak JW, Stancukas $\mathrm{MC}$, Laskowski $\mathrm{S}$, Dougherty $\mathrm{J}$, et al. Exercise prevents weight gain and alters the gut microbiota in a mouse model of high fat diet-induced obesity. PLoS One. 2014;9(3):e92193.

7. Queipo-Ortuno MI, Seoane LM, Murri M, Pardo M, Gomez-Zumaquero JM, Cardona F, et al. Gut microbiota composition in male rat models under different nutritional status and physical activity and its association with serum leptin and ghrelin levels. PLoS One. 2013;8:e65465.
8. Lambert JE, Myslicki JP, Bomhof MR, Belke DD, Shearer J, Reimer RA. Exercise training modifies gut microbiota in normal and diabetic mice. Appl Physiol Nutr Metab. 2015;40:749-52

9. Kang SS, Jeraldo PR, Kurti A, Miller ME, Cook MD, Whitlock $\mathrm{K}$, et al. Diet and exercise orthogonally alter the gut microbiome and reveal independent associations with anxiety and cognition. Mol Neurodegener. 2014;9:36.

10. Choi JJ, Eum SY, Rampersaud E, Daunert S, Abreu MT, Toborek M, et al. Exercise attenuates PCB-induced changes in the mouse gut microbiome. Environ Health Perspect. 2013;121:725-30.

11. Haywood BA, Black KE, Baker D, Mc Garvey J, Healey P, Brown RC. Probiotic supplementation reduces the duration and incidence of infections but not severity in elite rugby union players. Journal of Science and Medicine in Sport. 2014;17(4):356-360.

12.Clarke SF, Murphy EF, O'Sullivan O, Lucey AJ, Humphreys $M$, et al. Exercise and associated dietary extremes impact on gut microbial diversity. Gut. 2014;63:1913-1920.

13. Cairns SP. Lactic acid and exercise performance: culprit or friend? Sports Med. 2006;36:279-91.

14. Opitz D, Lenzen E, Opiolka A, Redmann M, Hellmich M, Bloch W, et al. Endurance training alters basal erythrocyte MCT-1 contents and affects the lactate distribution between plasma and red blood cells in T2DM men following maximal exercise. Can $\mathbf{J}$ Physiol Pharmacol. 2015;93:413-9.

15. Samuel BS, Shaito A, Motoike T, Rey FE, Backhed F, Manchester JK, et al. Effects of the gut microbiota on host adiposity are modulated by the short-chain fatty-acid binding G protein-coupled receptor, Gpr41. Proc Natl Acad Sci. 2008;105:16767-72.

16. Shephard RJ, Shek PN. Potential impact of physical activity and sport on the immune system-a brief review. Br J Sports Med. 1994;28:247- 55.

17. Engebretsen L, Soligard T, Steffen K, Alonso JM, Aubry M, Budgett R, et al. Sports injuries and illnesses during the London Summer Olympic Games 2012. Br J Sports Med. 2013; 47(7):407-414.

18. Soligard T, Steffen K, Palmer-Green D, Aubry M, Grant ME, Meeuwisse W, et al. Sports injuries and illnesses in the Sochi 2014 
Olympic Winter Games. Br J Sports Med. 2015;49(7):441-447.

19. Neville V, Gleeson M, Follan JP. Salivary IgA as a risk factor for upper respiratory infections in elite professional athletes. Med Sci Sports Exerc. 2008;40:1228-1236.

20. Jeukendrup AE, Vet-Joop K, Sturk A, Stegen JH, Senden J, Saris WH, et al. Relationship between gastro-intestinal complaints and endotoxaemia, cytokine release and the acute-phase reaction during and after a longdistance triathlon in highly trained men. Clin Sci (Lond). 2000;98(1):47-55.

21. Bhattacharyya A, Chattopadhyay R, Mitra S, Crowe SE. Oxidative stress: an essential factor in the pathogenesis of gastrointestinal mucosal diseases. Physiol Rev. 2014;94(2):329-54.

22. Xu J, Xu C, Chen X, Cai X, Yang S, Sheng $\mathrm{Y}$, et al. Regulation of an antioxidant blend on intestinal redox status and major microbiota in early weaned piglets. Nutrition. 2014;30(5):584-9.

23. Ghosh S, Dai C, Brown K, Rajendiran E, Makarenko S, Baker J, et al. Colonic microbiota alters host susceptibility to infectious colitis by modulating inflammation, redox status, and ion transporter gene expression. Am J Physiol Gastrointest Liver Physiol. 2011;301(81):3949.

24. Mardinoglu A, Shoaie S, Bergentall M, Ghaffari P, Zhang C, Larsson E, et al. The gut microbiota modulates host amino acid and glutathione metabolism in mice. Mol Syst Biol. 2015;11:834.

25. Thomas DT, Erdman KA, Burke LM. American College of Sports Medicine Joint Position Statement. Nutrition and Athletic Performance. Med Sci Sports Exerc. 2016;48(3):543-68.

26. Musch MW, Wang Y, Claud EC, Chang EB. Lubiprostone decreases mouse colonic inner mucus layer thickness and alters intestinal microbiota. Dig Dis Sci. 2013;58:668-77. 86.

27. Keely S, Kelly CJ, Weissmueller T, Burgess A, Wagner BD, Robertson $\mathrm{CE}$, et al. Activated fluid transport regulates bacterialepithelial interactions and significantly shifts the murine colonic microbiome. Gut Microbes. 2012;3:250-60.

28. Redondo N, Gheorghe A, Serrano R, Nova E, Marcos A. HYDRAGUT study: influence of hydration status on the GUT microbiota and their impact on the immune system. The FASEB J 2015;29(Suppl. 1):593.

29. Redondo N, Gheorghe A, Serrano R, Nova E, Marcos A. Hydragut study: influence of hydration status on the gut microbiota and their impact on the immune system. The FASEB Journal. 2015;29 (Suppl.1):593.

30. West NP, Pyne DB, Cripps AW, Hopkins WG, Eskesen DC, Jairath $A$, et al. Lactobacillus fermentum (PCC $\left.{ }^{\circledR}\right)$ supplementation and gastrointestinal and respiratory-tract illness symptoms: a randomised control trial in athletes. Nutr J. 2011; 11(10):30.

31. Pyne DB, West NP, Cox AJ, Cripps AW. Probiotics supplementation for athletesclinical and physiological effects. Eur J Sport Sci. 2015;15(1):63-72.

32. West NP, Horn PL, Pyne DB, Gebski VJ, Lahtinen SJ, Fricker PA, et al. Probiotic supplementation for respiratory and gastrointestinal illness symptoms in healthy physically active individuals. Clin Nutr. 2014;33(4):581-587.

33. Salarkia N, Ghadamli L, Zaeri F, Sabaghian Rad L. Effects of probiotic yogurt on performance, respiratory and digestive systems of young adult female endurance swimmers: a randomized controlled trial. Med J Islam Repub Iran. 2013;27(3):141-6.

34. Cox AJ, Pyne DB, Saunders PU, Fricker PA. Oral administration of the probiotic Lactobacillus fermentum VRI-003 and mucosal immunity in endurance athletes. $\mathrm{Br}$ J Sports Med. 2010;44(4):222-6.

35. Gleeson M, Bishop NC, Oliveira M, Tauler P. Daily probiotic's (Lactobacillus casei Shirota) reduction of infection incidence in athletes. Int $\mathbf{J}$ Sport Nutr Exerc Metab. 2011;21:55-64.

36. Lamprecht $M$, Bogner $S$, Schippinger G, Steinbauer K, Fankhauser F, Hallstroem S, et al. Probiotic supplementation affects markers of intestinal barrier, oxidation, and inflammation in trained men; a randomized, double-blinded, placebo-controlled trial. J Int Soc Sports Nutr. 2012;9(1):45.

37. Shing CM, Peake JM, Lim CL, Briskey D, Walsh NP, Fortes MB, et al. Effects of probiotics supplementation on gastrointestinal permeability, inflammation and exercise performance in the heat. Eur J Appl Physiol. 2014;114(1):93-103.

38. Jäger R, Shields KA, Lowery RP, De Souza EO, Partl JM, Hollmer C, et al. Probiotic Bacillus coagulans GBI-30, 6086 reduces exerciseinduced muscle damage and increases recovery. PeerJ. 2016;21;4:e2276. 